\title{
Liver Lymphoma
}

National Cancer Institute

\section{Source}

National Cancer Institute. Liver Lymphoma. NCI Thesaurus. Code C4949.

A rare lymphoma that arises from the liver and the bulk of the tumor is located in the liver. The most frequent types of lymphoma that arise from the liver are diffuse large Bcell lymphoma and mucosa-associated lymphoid tissue lymphoma. 